\section{References}

Ahrens, E. H., Jun., et al. (1950). Medicine, 29, 299. Anrep, G. V., and Barsoum, G. S. (1953). fournal of Physiology, 120, 427. Arthur, R. P., and Shelley, W. B. (1955). Fournal of Investigative Dermatology, 25,341 .

Brulé, M., and Cottet, J. (1942). La Presse Médicale, 50, 369.

Carey, J. B. (1958). Fournal of Clinical Investigation, 37, 1494

Carey, J. B., and Williams, G. (1961). Journal of the American Medical Assiciation, 176, 432.

Datta, D. V., and Sherlock, S. (1963). British Medical fournal, 1, 216.

Dreher, K. D., Schulman, J. H., and Hofmann, A. F. (1967). Fournal of Colloid and Interface Science, 25, 71 .

Heaton, K. W. (1972). Bile Salts in Health and Disease, p. 117. London, Churchill Livingstone.
Herndon, J. J. (1972). Archives of Internal Medicine, 130, 632.

Johns, W. H., and Bates, T. R. (1969). Fournal of Pharmaceutical Sciences, $58,179$.

Johns, W. H., and Bates, T. R. (1970). Fournal of Pharmaceutical Sciences, 59, 329.

Mitchell, R. G., Butt, H. R., and Code, C. F. (1954). Fournal of Clinical Investigation, 33, 1199.

Neale, G., et al. (1971). Gut, 12, 145

Osborn, E. C., et al. (1959). Lancet, 2, 1049.

Schachter, M. (1952). British Fournal of Pharmacology, 7, 646

Schoenfield, L. J. (1969). In Bile Salt Metabolism, ed. L. Schiff, p. 257. Springfield, Thomas.

Schoenfield, L. J., Sjovall, J., and Perman, E. (1967). Nature, 213, 93.

Varadi, D. P. (1974). Archives of Dermatology, 109, 678.

\title{
Neonatal Hyperthyroidism and Long-acting Thyroid Stimulator Protector
}

\author{
J. NUTT， F. CLARK， R. G. WELCH， R. HALL
}

British Medical fournal, 1974, 4, 695-696

\section{Summary}

Neonatal hyperthyroidism has been thought to result from transplacental passage of long-acting thyroid stimulator (L.A.T.S.) from a mother with Graves's disease. $A$ case is presented here in which no L.A.T.S. was detected in the mother or neonate but another immunoglobulin, L.A.T.S. protector, a specific human thyroid stimulator, was shown to be present in the mother's serum. This stimulator may have been the cause of the neonatal hyperthyroidism.

\section{Introduction}

Rosenberg et al. (1963) first suggested that neonatal hyperthyroidism might be caused by transplacental passage of longacting thyroid stimulator (L.A.T.S.). This immunoglobulin (IgG) is found in the serum of some patients with hyperthyroidism due to Graves's disease and has with few exceptions been present in the serum of both the mother and child in cases of neonatal hyperthyroidism. Thomson and Riley (1966), however, described a case in which L.A.T.S. was not detectable in the mother or child.

Adams and Kennedy (1967) noted the existence of another immunoglobulin in the serum of patients with Graves's disease, which they termed L.A.T.S. protector (L.A.T.S.P.), since it was able to compete with L.A.T.S. for binding to human thyroid fractions in vitro but did not stimulate mouse thyroid in the in-vivo McKenzie bioassay (Adams and Kennedy, 1971) or monkey thyroid (Knight and Adams, 1973). L.A.T.S.P. has been shown to stimulate human thyroid both in vivo (Adams et al., 1974) and in vitro (Kendall-Taylor, 1973; Shishiba et al., 1973), and since unlike L.A.T.S. it is present in most patients with Graves's disease (Stewart et al., 1973) it has been suggested that it is likely to be a human thyroid stimulator responsible for the hyperthyroidism of Graves's disease.

University Department of Medicine, Newcastle upon Tyne NE1 4LP J. NUTT, PH.D., Research Associate

We report a case of neonatal hyperthyroidism in which no L.A.T.S. could be detected in the mother or infant, but in which L.A.T.S.P. was present in the mother's serum.

\section{Patients}

The mother, aged 25 years, developed hyperthyroidism due to Graves's disease at the age of 12 , when her basal metabolic rate was $+45 \%$. She was treated initially with potassium perchlorate and later with carbimazole. She relapsed on several occasions when antithyroid drugs were withdrawn and at age 20 underwent a partial thyroidectomy. Thyroid tissue showed changes compatible with hyperthyroidism, including focal lymphocytic infiltration with formation of germinal centres but no Askanazy cell change. She remained euthyroid thereafter. Her baby was born when she was 23 years of age. Eye signs of Graves's disease were present throughout, consisting of bilateral exophthalmos and left-sided lid retraction, but these did not necessitate treatment. At no time was pretibial myxoedema observed though slight splenic enlargement was noted before the thyroidectomy.

The Child was born three weeks prematurely and weighed 2,180 g. At birth she was noted to be hyperkinetic, with a tachycardia of 140/ min when resting, staring eyes, and a goitre. A thyroid function test at 3 days confirmed hyperthyroidism and she was treated with carbimazole $2.5 \mathrm{mg}$ six-hourly and Lugol's iodine 1 drop eight-hourly from the tenth to 27 th days with marked clinical improvement. Treatment was then withdrawn. Fourteen days later there was clinical and biochemical evidence of relapse of the hyperthyroidism and treatment was reinstituted in decreasing doses till she was 9 months of age. Withdrawal was uneventful and she subsequently thrived.

\section{Methods}

Routine thyroid function tests included measurement of the serum protein-bound iodine (P.B.I.) on an AutoAnalyzer, residual thyroid hormone binding test (Thyopac-3; Amersham), and determination of the effective thyroxine ratio (E.T.R.; Mallinkrodt).

Thyroid-stimulating hormone (T.S.H.) was measured by radioimmunoassay using the method of Hall et al. (1971) with Medical Research Council H.T.S.H. 68/38 as standard. The thyrotrophin-releasing hormone test (T.R.H. test) was performed as described by Ormston et al. (1971). Thyroglobulin antibody levels were determined as described by Evered et al. (1973).

L.A.T.S. was measured using a modification of the McKenzie bioassay (Nutt et al., 1974). L.A.T.S.P. was measured as described by Adams and Kennedy (1967) using a partially purified thyroid fraction of L.A.T.S. absorbing activity(L.A.A.). This was 
prepared from human thyroid tissue by homogenization in a buffer, high-speed centrifugation, and application of the supernatant to a Sephadex G-200 column to remove thyroglobulin. L.A.A. was eluted in the $4 \mathrm{~S}$ fraction as described by Smith (1970). The amount of L.A.A. which almost completely neutralized a standard L.A.T.S. serum was determined by bioassay. Serum to be tested for L.A.T.S.P. was heat-deactivated for one hour at $56^{\circ} \mathrm{C}$ and then mixed with the appropriate quantity of L.A.A. at $4^{\circ}$ C. After 15 minutes the standard L.A.T.S. serum was added, the mixture then being concentrated by ultrafiltration and assayed. When L.A.T.S.P. is present in the system inhibition of the response to the standard L.A.T.S. serum by L.A.A. is prevented so that a L.A.T.S. response is obtained despite the presence of previously neutralizing quantities of L.A.A.

\section{Results}

The results of serial thyroid function tests on the mother are shown in table I. Thyroglobulin antibodies were detected in high titre in her serum $\left(>1 / 2 \times 10^{6}\right)$. Serial measurements of the E.T.R. in the child are shown in the fig. The results of tests for L.A.T.S.P. are given in table II. No L.A.T.S. was detectable in the mother's serum after the birth of the baby nor in the child 10 and 38 days and six months after birth. When the L.A.T.S.P. assay system was used, however, a significant increase $(P<0.05)$ in response was obtained with the L.A.T.S. standard and L.A.A. in the presence of serum from the mother compared with L.A.T.S. standard and L.A.A. alone. This indicated the presence of L.A.T.S.P. in the mother's serum. Serum from the baby was insufficient to measure L.A.T.S.P.

TABLE I-Results of Serial Thyroid Function Tests on Mother

\begin{tabular}{l|c|c|c|c}
\hline & $\begin{array}{c}\text { Serum } \\
\text { P.B.I. } \\
(\mu \mathrm{g} / 100 \mathrm{ml})\end{array}$ & $\begin{array}{c}\text { Serum } \\
\text { Thyopac-3 }\end{array}$ & $\begin{array}{c}\text { Free } \\
\text { Thyroxine } \\
\text { Index }\end{array}$ & $\begin{array}{c}\text { Serum } \\
\text { T.S.H. } \\
(\mu \mathrm{U} / \mathrm{ml})\end{array}$ \\
\hline $\begin{array}{c}\text { Age 20 years; time of } \\
\text { inadequate antithyroid } \\
\text { medication }\end{array}$ & 9.6 & 0.92 & 10.4 & 2.4 \\
$\begin{array}{c}\text { Age 22 years; 14 months after } \\
\text { thyroidectomy }\end{array}$ & $5.0^{*}$ & $1.30^{*}$ & $3.9^{*}$ & 16.5 \\
$\begin{array}{c}\text { Age 23 years; 30 months after } \\
\text { thyroidectomy; six months } \\
\text { pregnant }\end{array}$ & 10.8 & 1.42 & 7.6 & 0.7 \\
$\begin{array}{c}\text { Age 24 years; two months after } \\
\text { delivery }\end{array}$ & $10.6^{*}$ & $1.21^{*}$ & $8.8^{*}$ & $0.5 \dagger$ \\
\hline $\begin{array}{c}\text { Normal range (95\% } \\
\text { confidence limits) }\end{array}$ & $3.1-8.3$ & $0.92-1.20$ & $2.5-9.0$ & $0.5-5.0$ \\
\hline
\end{tabular}

*On oral contraceptives.
$\dagger$ No rise in T.S.H. after T.R.H.
TABLE II-Results of Tests for L.A.T.S. and L.A.T.S.P. on Mother Using Serum Taken Seven Months after Birth of Child

\begin{tabular}{|c|c|c|}
\hline Sample and Volume per Assay Mouse & Assay Response* & Control Response* \\
\hline \multirow{2}{*}{$\begin{array}{l}\text { Mother, } 2 \mathrm{ml} \\
\text { L.A.T.S. standard } 75 \mu \mathrm{\mu l} \dagger \\
\text { L.A.T.S. standard } 75 \mu \mathrm{\mu l}+\text { L.A.A. } \\
50 \mathrm{mg} \text { equivalent thyroid tissue } \dagger \\
\text { L.A.T.S. standard } 75 \mu \mathrm{\mu l} \text { + L.A.A. } \\
50 \mathrm{mg} \text { equivalent thyroid tissue } \\
+1.5 \mathrm{ml} \text { from mother }\end{array}$} & $\begin{array}{l}83 \pm 15 \\
383 \cdot 0 \pm 151 \cdot 4 \\
114 \cdot 1 \pm 30 \cdot 8\end{array}$ & $\begin{array}{l}91 \cdot 8 \pm 22 \cdot 1 \\
58 \cdot 0 \pm 8 \cdot 5 \\
58 \cdot 0 \pm 8 \cdot 5\end{array}$ \\
\hline & $395 \cdot 0 \pm 102 \cdot 8$ & $58 \cdot 0 \pm 8 \cdot 5$ \\
\hline
\end{tabular}

* Response is measured by (blood radioactivity 24 hours after injection of stimulus)/ (blood radioactivity at time of injection of stimulus) $\times 100 \%$.

†Final volume per mouse adjusted to $3 \mathrm{ml}$.

\section{Discussion}

The role of L.A.T.S. in the development of hyperthyroidism in Graves's disease was questioned by McKenzie (1972) and Solomon and Chopra (1972). The relationship of L.A.T.S. to hyperthyroidism in the neonate was discussed by Maisey and Stimmler (1972), and here the evidence for a direct effect is much stronger though some discrepancies still exist.

The evidence for Graves's disease in the mother in our case was both clinical and biochemical, the patient having been thyrotoxic and having the eye signs associated with Graves's disease. There was also strong clinical and biochemical evidence for the neonatal hyperthyroidism. The absence of circulating L.A.T.S. in the mother and baby soon after birth was surprising but the presence of L.A.T.S.P. in the mother's serum suggest that this immunoglobulin may also have a role in the pathogenesis of neonatal hyperthyroidism. Possibly also the case of neonatal hyperthyroidism reported by Thomson and Riley (1966) was due to L.A.T.S.P. The mother had the eye signs of Graves's disease and thyroglobulin antibodies were present in her serum. As in our case L.A.T.S. was not detectable in the mother or the child.

In the present case a raised serum T.S.H. level was found in the mother 14 months after partial thyroidectomy. This is a common finding after thyroidectomy but subsequent tests showed that the serum T.S.H. level had fallen to the normal range, that there was no response to T.R.H., and that routine thyroid function indices had moved to the upper end of the normal range. This trend towards recurrence of the original disorder may have been due to L.A.T.S.P.

We are grateful to the Medical Research Council and Roche Products Ltd. for financial support. We acknowledge the technical help of Mr. D. Weightman with the T.S.H. assays and help from Miss A. Brown.

\section{References}

Adams, D. D., and Kennedy, T. H. (1967). Fournal of Clinical Endocrinology and Metabolism, 27, 173 .

Adams, D. D., and Kennedy, T. H. (1971). Fournal of Clinical Endocrinology and Metabolism, 33, 47 .

Adams, D. D., et al. (1974). Fournal of Clinical Endocrinology and Metabolism.

In press.
Evered, D. C., et al. (1973). British Medical fournal, 1, 657.

Hall, R., Amos, J., and Ormston, B. J. (1971). British Medical fournal, 1, 582.

Kendall-Taylor, P. (1973). British Medical fournal, 3, 72.

Knight, A., and Adams, D. D. (1973). Proceedings of the University of Otago Medical School, 51, 49.
.

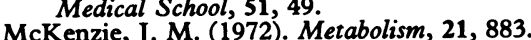

McKenzie, J. M. (1972). Metabolism, 21, 883.

Nutt, J., Humphreys, K., and Clark, F. (1974). Fournal of Endocrinology. In press.

Ormston, B. J., et al. (1971). Lancet, 2, 10.

Rosenberg, D., Grand, M. J. H., and Silbert, D. (1963). New England fournal of Medicine, 268, 292.

Shishiba, Y., et al. (1973). Fournal of Clinical Endocrinology and Metabolism, 36, 517 .

Smith, B. R. (1970). Fournal of Endocrinology, 46, 45.

Solomon, D. H., and Chopra, I. J. (1972). Mayo Clinic Proceedings, 47, 803. Stewart, R. D. H., Adams, D. D., and Kennedy, T. H. (1973). Proceedings of the Endocrinology Society of Australia, 16, 40.

Thomson, J. A., and Riley, I. D. (1966). Lancet, 1, 635.
Serial thyroid function tests and treatment of child from Serial
birth. 